\title{
Batch Studies for Methylene Blue Removal and Recovery by Untreated Coffee Residues
}

\author{
Odysseas Kopsidas \\ Laboratory of Simulation of Industrial Processes, Department of Industrial Management and Technology, University of Piraeus, \\ Piraeus 18534, Greece
}

\begin{abstract}
This paper reports the practicability of using coffee residues to remove widely used basic dyes like MB (Methylene Blue) from wastewaters. The effect of different batch system parameters, namely stirring speed, $\mathrm{pH}$, initial dye concentration and contact time were studied. Moreover, in continuous fixed-bed column systems, the effects of parameters such as bed-depth, flow rate and initial dye concentration were examined. The experimental batch systems data were simulated using (a) Freundlich, Langmuir and Sips isotherm models and (b) 1st order, 2nd order, and intra-particle kinetic models. The results revealed that the MB is fairly adsorbed on coffee residues. This process could be a low cost technique for the removal of basic dyes from aqueous systems.
\end{abstract}

Key words: Adsorption, desorption, column, MB (Methylene Blue), coffee residues, wastewaters.

\section{Introduction}

Many industries, such as paper, plastics, food, printing, leather, cosmetics and textile, use dyes in order to color their products [1]. In textile industries about $10-15 \%$ of the dye gets lost in the effluent during the dyeing processes which are harmful products and may cause cancer epidemics [2]. Dyes usually have a synthetic origin and complex aromatic molecular structures which make them more stable and more difficult to biodegrade [3]. The industrial runoffs are usually discarded into rivers and lakes, altering the biological stability of surrounding ecosystems [4]. Therefore, removal of dyestuffs from wastewater has received considerable attention over the past decades [5].

In wastewater treatment, various methods applied to remove dyes include photocatalytic degradation [6], membrane separation, chemical oxidations [7] and electrochemical process. Among the above mentioned techniques of dye removal, the process of adsorption gives the best results as it can be used to remove

Corresponding author: Odysseas Kopsidas, Ph.D., main research field: environmental economics. different types of coloring materials [8].

Adsorption onto activated carbon is the most widespread technology for the removal of pollutants from water and wastewaters. The disadvantage of activated carbon is its high cost [9]. Hence, it is of pivotal importance thence of low-cost substitute absorbents to replace activated carbons. Various types of untreated biomass have been reported to have a use in dye removal: peanut husk, palm kernel fibre [10], Turbinaria turbinate alga, graphene, defatted jojoba and sugar beet pulp [11]. The sorption efficiency of several adsorbents is presented in Table 1.

Further, numerous pretreated lignocellulosic materials are used to remove dyes in water and wastewater. Pyrolyzed date pits, date stones and Turbinaria turbinate alga have proved to be effective adsorbents.

\section{Materials}

Coffee residues and others similar byproducts like coffee husks and coffee grounds have been investigated to remove various dyes and heavy metals from aqueous solutions. Coffee husks have been used for the removal of $\mathrm{Cu}$ (II), $\mathrm{Cr}$ (VI), $\mathrm{Cd}$ (II) and $\mathrm{Zn}$ (II), 
coffee grounds for Nylosan Red N-2RBL and degreased coffee bean for Malachite Green. It is reported that the removal of Remazol Brilliant Blue $\mathrm{RN}$ and Basic Blue $3 \mathrm{G}$ is using coffee residues, focusing on batch processes and not on continuous systems [12].

In the current study, the adsorption capacities of coffee residues to remove MB (Methylene Blue) from aqueous solutions were investigated. Both batch and continuous fixed-bed-column systems were investigated. As regards the fixed-bed-column systems filed with coffee residues, various bed-depths, flow rates and initial dye concentrations were examined for the first time.

\section{Methods}

Coffee residues, a low-cost material acquired from different cafeterias in the city of Piraeus (Greece) were used as adsorbent. This adsorbent was washed with distilled water and dried at $110{ }^{\circ} \mathrm{C}$ for $24 \mathrm{hrs}$ to remove the humidity.

The dye used herein in batch and column experiments was $\mathrm{MB}\left(\mathrm{C}_{16} \mathrm{H}_{18} \mathrm{ClN}_{3} \mathrm{~S} \cdot 3 \mathrm{H}_{2} \mathrm{O}\right.$, molecular weight $\left.=373.90 \times 10^{-3} \mathrm{~kg} \cdot \mathrm{mol}^{-1}\right)$ supplied by Sigma-Aldrich. A stock solution was prepared by dissolving a specific amount of MB (humidity 22\%) in distilled water. Working solutions were 3-140 $\mathrm{mg} \cdot \mathrm{L}^{-1}$. MB concentrations were determined by measuring the absorbent values in each experiment with HACH DR4000U UV-VIS spectrophotometer at $\lambda=664 \mathrm{~nm}$.

Isotherms were obtained from batch experiments. Accurately weighted quantities of approximately $0.5 \mathrm{~g}$ coffee residues were transferred to $0.8 \mathrm{~L}$ bottles, where $0.5 \mathrm{~L}$ adsorbate solution were added. The temperature was $23{ }^{\circ} \mathrm{C}$, the $\mathrm{MB}$ initial concentration ranged from $C_{0}=1.5 \mathrm{mg} \cdot \mathrm{L}^{-1}$ to $150 \mathrm{mg} \cdot \mathrm{L}^{-1}$. The bottles are sealed and mechanically agitated for a period of 7 days. The 7-day period was determined after optimization analysis, with agitation periods varying from $4 \mathrm{hrs}$ to 14 days, to ensure that nearly equilibrium conditions were achieved. The final concentrations were determined. Concentrations (before and after equilibrium) from each bottle represented one point on the adsorption isotherm plots. The $\mathrm{pH}$ was near 7.5.

Batch experiments were carried out at stirring speeds from 65 to $664 \mathrm{rpm}, \mathrm{pH}$ varied from 1.54 to 12.9 , the adsorption temperature varied from 23 to $70{ }^{\circ} \mathrm{C}$, initial dye concentration from 3 to $140 \mathrm{mg} \cdot \mathrm{L}^{-1}$ for a maximum contact time up to $95 \mathrm{~min}$. Samples were taken at 5 minutes intervals and the $\mathrm{MB}$ concentration was measured. The reactor, containing $V=1 \mathrm{~L}$ aqueous solution of dye was placed in a water bath to maintain constant temperature at the desired level.

The study of the coffee residues by SEM (Scanning Electron Microscopy) was conducted at the Institute of Materials Science, National Centre for Scientific Research 'Demokritos', using an FEI Inspect SEM.

The concentration of output solution was measurement at $\lambda=664 \mathrm{~nm}$ and using $\mathrm{HACH}$ DR4000U UV-vis spectrophotometer. Finally, pH measurements were made using a digital $\mathrm{pH}$ meter, Multi Lab model 540.

\section{Results}

The SEM micrographs for coffee residues before and after MB adsorption are presented in Fig. 1. The coffee residues particle in Fig. 1(a) with magnification 7,500X shows some pores. The surface texture of this particle is relatively rough as it can be observed in Fig 1(b) with magnification $30,000 \mathrm{X}$. The adsorption conditions were $\mathrm{C}_{0}=140 \mathrm{mg} \cdot \mathrm{L}^{-1}, \mathrm{t}=95 \mathrm{~min}, \mathrm{~m} / \mathrm{V}=1$ $\mathrm{g} \cdot \mathrm{L}^{-1}$, agitation speed $=664 \mathrm{rpm}$. The texture of the coffee residues particles after MB adsorption in Fig. $1(d)$ is rougher comparing to the same material before MB adsorption, presented in Fig. 1(b). This fact indicates the swelling effect on the lignocellulosic particles after MB adsorption.

Three isotherm models including Freundlich (1906), Langmuir (1916) and Sips (1948) [13] equations were 


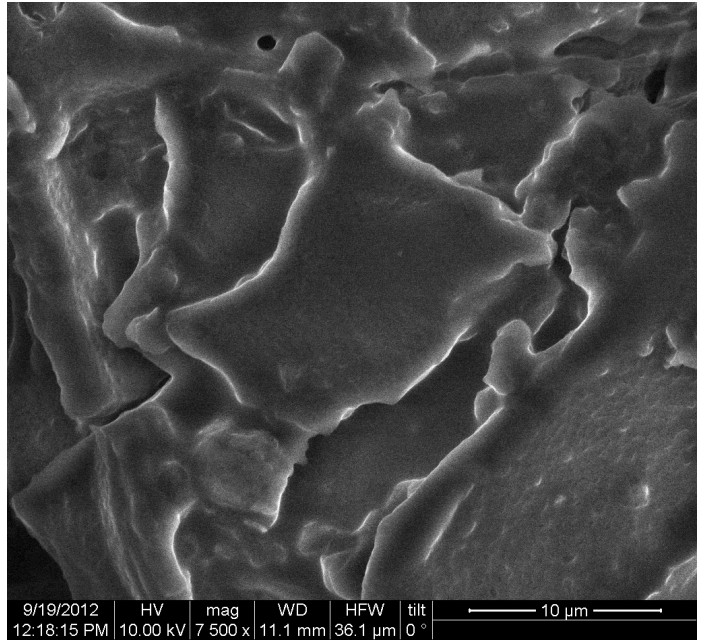

(a)

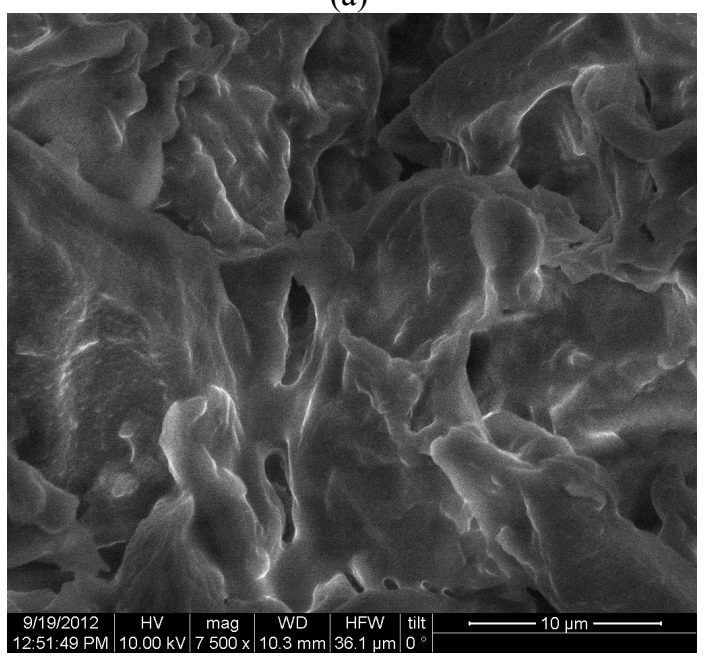

(c)

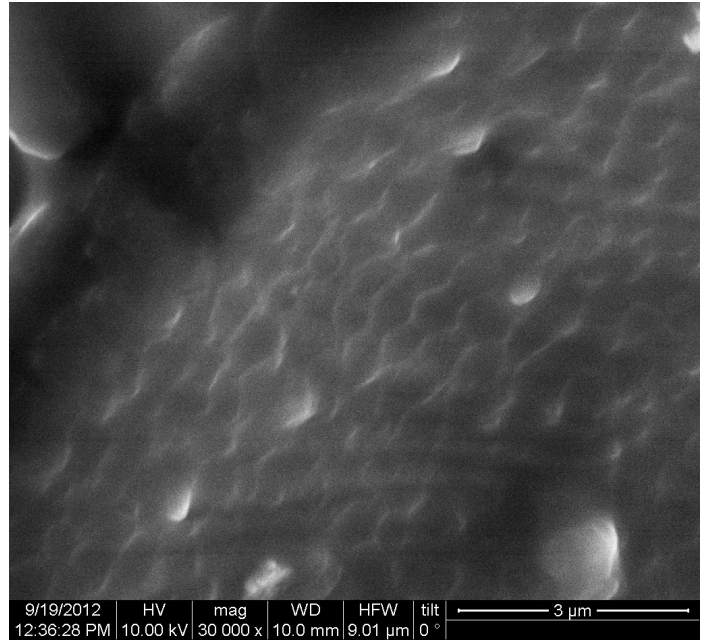

(b)

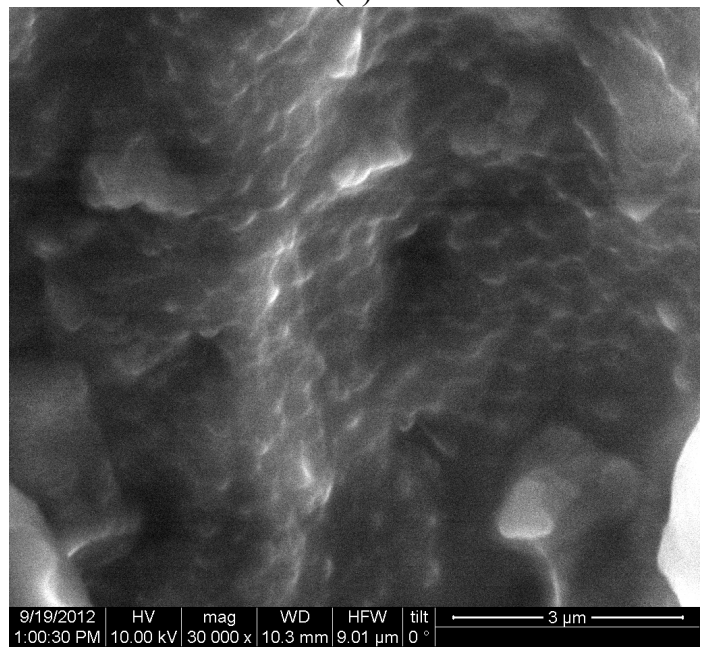

(d)

Fig. 1 SEM analysis for coffee residues.

used to fit the experimental data. Freundlich isotherm model assumes that the surface of absorbent is where heterogeneous and polymolecular layer adsorption takes place. This model can be described byEq. (1):

$$
q=K_{F} \cdot\left(C_{e}\right)^{\frac{1}{n}}
$$

where $q$ is the amount adsorbed per unit mass of the adsorbent $\left(\mathrm{mg} \cdot \mathrm{g}^{-1}\right), C_{e}$ is the equilibrium concentration of MB adsorbed $\left(\mathrm{mg} \cdot \mathrm{L}^{-1}\right), K_{F}\left[\left(\mathrm{mg} \cdot \mathrm{g}^{-1}\right)\left(\mathrm{L} \cdot \mathrm{mg}^{-1}\right)^{1 / \mathrm{n}}\right]$ is the Freundlich isotherm constant related to adsorption capacity and $n$ is the Freundlich isotherm constants related to adsorption intensity. In cases where the isotherm experimental data approximates the Freundlich equation, the parameters $K_{F}$ and $n$ can be estimated either by plotting $\log q$ versus $\log C_{e}$ either by NLRA (Non-Linear Regression Analysis). The linear form of the Freundlich isotherm model can be defined by Eq. (2):

$$
\log q=\log K_{F}+\frac{1}{n} \log C_{e}
$$

The Langmuir (1916) isotherm model is given as:

$$
q=\frac{K_{L} q_{m} C_{e}}{1+K_{L} C_{e}}
$$

Moreover, this equation in linearized form is:

$$
\frac{1}{q}=\left(\frac{1}{q_{m}}\right)+\left(\frac{1}{K_{L} \cdot q_{m}}\right) \cdot\left(\frac{1}{C_{e}}\right)
$$

where $K_{L}$ is the Langmuir constant related to the energy of adsorption $\left(\mathrm{L} \cdot \mathrm{mg}^{-1}\right)$ and $q_{m}$ is the amount of $\mathrm{MB}$ 
adsorbed $\left(\mathrm{mg} \cdot \mathrm{g}^{-1}\right)$ when saturation is attained. In cases where the isotherm experimental data approximates the Langmuir equation, the parameters $K_{L}$ and $q_{m}$ can be estimated either by plotting $1 / q$ versus $1 / C_{e}$ either by NLRA.

Numerous studies incorporate another important parameter, $\mathrm{R}_{L}$, namely the separation factor. The value of $R_{L}$ indicates the type of the isotherm to be either unfavorable $\left(R_{L}>1\right)$, linear $\left(R_{L}=1\right)$, favorable $\left(0<R_{L}\right.$ $<1)$ or irreversible $\left(R_{L}=0\right)$ and is expressed by Eq. (5):

$$
R_{L}=\frac{1}{1+K_{L} \cdot C_{0}}
$$

where $C_{0}$ is the initial dye concentration $\left(\mathrm{mg} \cdot \mathrm{L}^{-1}\right)$ and $K_{L}$ is the Langmuir constant $\left(\mathrm{L} \cdot \mathrm{mg}^{-1}\right)$.

Sips (1948) [13] isotherm model is a combination of the Langmuir and Freundlich isotherm type models and is expected to describe heterogeneous surface better. The Sips equation is presented by Eq. (6):

$$
q=\frac{q_{m} \cdot\left(K_{L} \cdot C_{e}\right)^{1 / n}}{1+\left(K_{L} \cdot C_{e}\right)^{1 / n}}
$$

where $K_{L}\left(\mathrm{~L} \cdot \mathrm{mg}^{-1}\right), \quad q_{m}\left(\mathrm{mg} \cdot \mathrm{g}^{-1}\right)$ is the Langmuir constants and $n$ the Freundlich constant. These parameters can be estimated by NLRA.

MB adsorption isotherms experimental data for untreated coffee residues are presented in Fig. 2. The theoretical curves are estimated for the above mentioned three models. The parameter values of these models are shown in Table 1. These parameters were obtained by NLRA. The SEE (Standard Error of Estimate) was calculated in each case as Eq. (7):

$$
S E E=\sqrt{\sum_{i=1}^{n^{\prime}}\left(y_{i}-y_{i, \text { theor }}\right)^{2} /\left(n^{\prime}-p^{\prime}\right)}
$$

where $y_{i}$ is the experimental value of the depended variable, $y_{i, \text { theor }}$ is the theoretical or estimated value of the depended variable, $n^{\prime}$ is the number of the experimental measurements and $p^{\prime}$ is the number of parameters (the difference $n-p^{\prime}$ being the number of the degrees of freedom.

The fitting of the Sips adsorption model to the present data was the most satisfactory for MB adsorption, better than the other two isotherm models, as shown by the corresponding SEE-values given in Table 1. The fitting of the Langmuir's adsorption model to the present data was also satisfactory but to a lesser degree than the Sips model. The $R_{L}$ values were found to be $0.236-0.935$, i.e. $0<R_{L}<1$ for all MB concentrations $C_{0}$ in the range of $3-140 \mathrm{mg} \cdot \mathrm{L}^{-1}$.

In order to make adsorption mechanism more clear, the adsorption data were fitted using the pseudo-first order, the pseudo-second order and the intra-particle diffusion kinetic model.

The Lagergren (1898) [12] non-linear pseudo-first order equation is given as Eq. (8):

$$
q-q_{t}=q \cdot e^{-k \cdot t}
$$

where $q$ and $q_{t}\left(\mathrm{mg} \cdot \mathrm{g}^{-1}\right)$ are the amounts of MB dye adsorbed per unit mass of the adsorbent at equilibrium time $(t \rightarrow \infty)$ and adsorption time $t$ (min), respectively, while $k\left(\mathrm{~min}^{-1}\right)$ is the pseudo-first order rate constant for the adsorption process. Moreover:

$$
q=\left(C_{0}-C_{e}\right) V / m \text { and } q_{t}=\left(C_{0}-C\right) V / m
$$

where $\mathrm{C}, \mathrm{C}_{0}$ and $\mathrm{C}_{\mathrm{e}}\left(\mathrm{mg} \cdot \mathrm{L}^{-1}\right)$ are the concentrations of $\mathrm{MB}$ in the bulk solution at time $t, 0$ and $\infty$, respectively, while $m(\mathrm{~g})$ is the weight of the adsorbent used, and $V(\mathrm{~mL})$ is the solution volume. Further modification of Eq. (9) in logarithmic form gives:

Table 1 Isotherms' parameters of Methylene Blue dsorption on coffee residues.

\begin{tabular}{llllll}
\hline & $K_{F}\left[\left(\mathrm{mg} \cdot \mathrm{g}^{-1}\right)\left(\mathrm{L} \cdot \mathrm{mg}^{-1}\right)^{1 / \mathrm{n}}\right.$ & $n$ & $K_{L}\left(\mathrm{~L} \cdot \mathrm{mg}^{-1}\right)$ & $q_{m}\left(\mathrm{mg} \cdot \mathrm{g}^{-1}\right)$ & SEE \\
\hline Freundlich & 3.555 & 1.612 & & & 2.397 \\
Langmuir & & & 0.0230 & 78.90 & 2.197 \\
Sips & 1.195 & 0.0111 & 109.27 & 2.168 \\
\hline
\end{tabular}




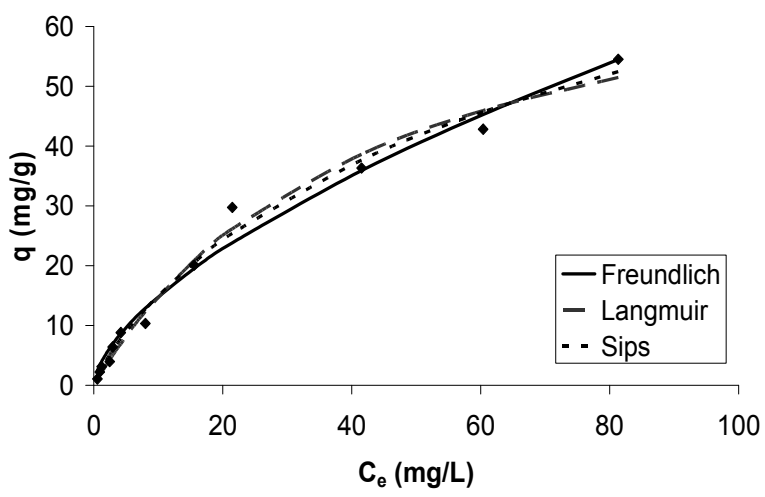

Fig. 2 Isotherm's parameters of adsorption of coffee residues.

$$
\ln \left(q-q_{t}\right)=\ln q-k \cdot t
$$

The pseudo-second order equilibrium adsorption model equation is given as Eq. (11):

$$
q_{t}=q-\left[q^{-1}+k_{2} t\right]^{-1} \text { or } q_{t}=q-\frac{1}{\frac{1}{q}+k_{2} t}
$$

where $k_{2}\left(\mathrm{~min}^{-1}\right)$ is the rate constant of second order adsorption.

The intra-particle diffusion model based on the theory proposed by Weber and Morris (1963) [9] is expressed as Eq. (12):

$$
q_{t}=c+k_{p} \cdot \sqrt{t}
$$

where $k_{p}\left[\mathrm{mg}\left(\mathrm{g} \cdot \mathrm{min}^{0.5}\right)^{-1}\right]$ is the intra-particle diffusion rate constant and $c\left(\mathrm{mg} \cdot \mathrm{g}^{-1}\right)$ is a constant related to the thickness of boundary. A value of $c$ close to zero indicates that diffusion is the only controlling step of the adsorption process.

The stirring speed was studied between 65 and 664 $\mathrm{rpm}$ at constant dye concentration $14 \mathrm{mg} \cdot \mathrm{L}^{-1}, \mathrm{pH}$ equals 7 and stirring time of $95 \mathrm{~min}$. The correlation between the first-order rate constant $\mathrm{k}$ for the $\mathrm{MB}$ absorption by coffee residues is shown in Fig. 3. The rate constant is generally increasing with stirring speed up to $200 \mathrm{rpm}$ were a level-off is reached.

According to the literature, the $\mathrm{pH}$ of the aqueous solution is one of the most important parameters of the adsorption process. The effect of the initial $\mathrm{pH}$ on the
MB adsorption onto coffee residues is illustrated in Fig. 4. The range of $\mathrm{pH}$ studied was from 2 to 12 . As can be seen the rate constant increases linearly by $\mathrm{pH}$ increasing.

The effect of initial MB concentration on adsorption on coffee residues is shown in Fig. 5. The kinetic parameters of the above mentioned three kinetic models were estimated using NLRA and are presented in Table 2. As can be seen, the SEE values are lower for the intra-particle diffusion kinetic model indicating better fitting to the experimental data. In addition the pseudo-second order kinetic model had better fitting that the pseudo-first one.

The temperature variation from $20{ }^{\circ} \mathrm{C}$ to $70{ }^{\circ} \mathrm{C}$ on $\mathrm{MB}$ uptake by coffee residues revealed that increase in temperature of the process enhanced better adsorption of MB from bulk solution. The conditions under which they became the experiments with different temperature were $\mathrm{pH}=8$, the initial concentration was $14 \mathrm{mg} \cdot \mathrm{L}^{-1}$,

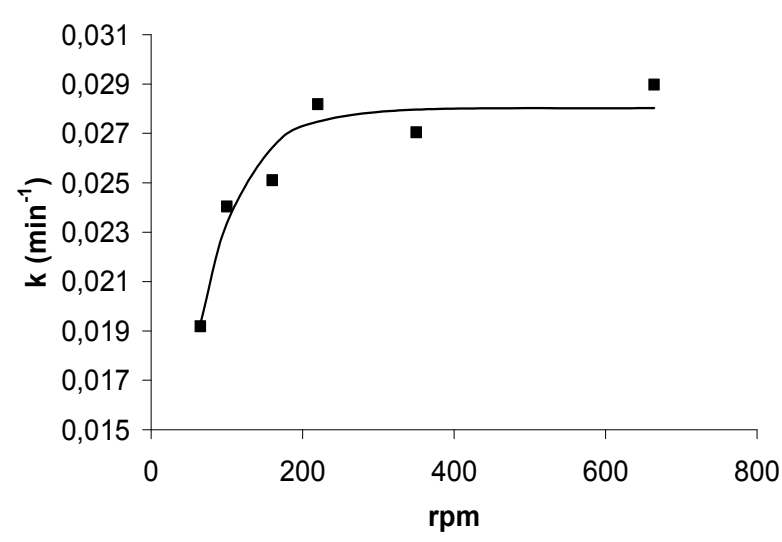

Fig. 3 Effect of stirring speed.

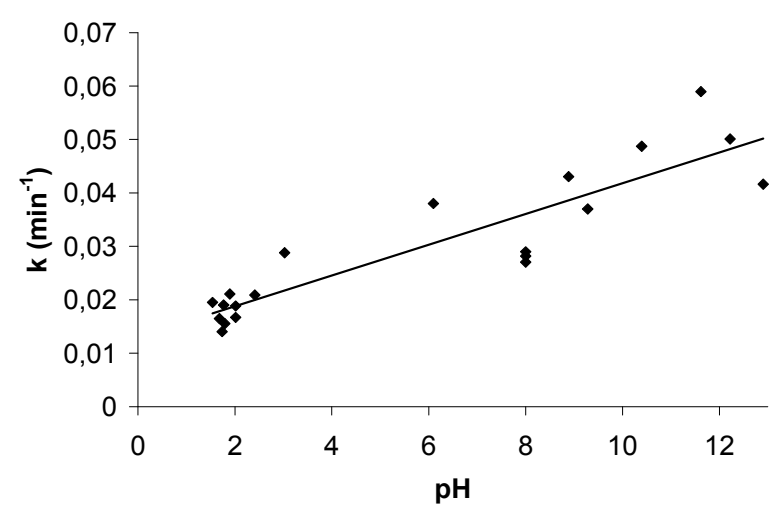

Fig. 4 Effect of pH. 


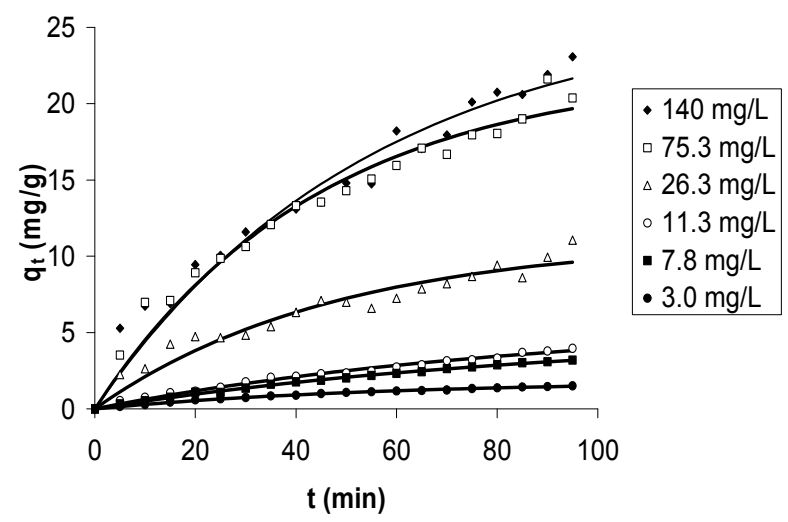

Fig. 5 Effect of initial MB concentration.

the stirring speed was $600 \mathrm{rpm}$ and the dose of coffee residues was $1 \mathrm{~g}$. Increase in temperature increased entropy of the system which yielded more chances of adsorption. The change in adsorption rate constant $\mathrm{k}$ as a function of adsorption temperatures is presented in Fig. 6.

The rate constant $\mathrm{k}$ of the Lagergren model follows the Arrhenius law:

$$
k=p \cdot \exp (-E / R T)
$$

The activation energy $E\left(\mathrm{~kJ} \cdot \mathrm{mol}^{-1}\right)$ for the adsorption of MB on untreated coffee residues can be estimated by linear regression of $\operatorname{lnk}$ on $1 / T$. This activation energy was found to be $27.4 \mathrm{~kJ} \cdot \mathrm{mol}^{-1}$ or $6.57 \mathrm{kcal} \cdot \mathrm{mol}^{-1}$. The frequency factor of Eq. (13) was $p=1,236 \mathrm{~min}^{-1}$. Consequently, the intra-particle diffusion, which is a physical process, is probably the controlling step of the adsorption process. The parameters of fixed-bed column systems for coffee residues are shown in Table 3.

This study is a research on the adsorption capacity of the coffee residue and its application to industrial scale. There is object for further research to determine the coffee residues quantity by region distribution and corresponding exploitation by industrial scale unit.

The MB adsorption capacity for various lignocellulosic materials found in the literature was compared to the coffee residues adsorption capacity estimated in the present work (Table 4). The adsorption capacity of the coffee residue was better than the adsorption capacity of other waste biomass such as peanut husk, turbinaria turbinate alga, and wheat straw. The adsorption capacities of various coffee residues/byproducts found in the literature are shown in Table 5. The coffee residues adsorption capacity found in the present work was close to the average of the Freundlich and Langmuir capacities, i.e., $K_{F}$ and $q_{m}$ respectively, reported in the literature.

The present study is a part of continues involvement of our Research Group in the study of wastewater treatment using original and modified (pretreated) lignocellulosic biomass as potential adsorbents. Previous study of our Group gave Langmuir capacity $q_{m}=38.7 \mathrm{mg} \cdot \mathrm{g}^{-1}$ for pine sawdust, significantly lower comparing to $q_{m}=78.9 \mathrm{mg} \cdot \mathrm{g}^{-1}$ for the coffee residues studied in the present work.

Table 2 Kinetic parameters of Methylene Blue adsorption on coffee residues.

\begin{tabular}{lllllll}
\hline$C_{0}\left(\mathrm{mg} \cdot \mathrm{L}^{-1}\right)$ & 140 & 75.3 & 26.3 & 11.3 & 7.8 & 3.0 \\
\hline First order & & & & & & \\
$\mathrm{k}$ & 0.0183 & 0.0227 & 0.0211 & 0.0113 & 0.0107 & 0.0176 \\
$\mathrm{q}_{\mathrm{e}}$ & 28.78 & 22.26 & 11.11 & 5.79 & 4.98 & 1.82 \\
$\mathrm{SEE}$ & 1.2827 & 0.9917 & 0.7150 & 0.1271 & 0.0515 & 0.0243 \\
Second order & & & & & \\
$\mathrm{K}_{2}$ & 0.000376 & 0.000604 & 0.001139 & 0.000796 & 0.000823 & 0.004587 \\
$\mathrm{q}_{\mathrm{e}}$ & 37.81 & 30.99 & 15.42 & 9.27 & 8.18 & 2.74 \\
$\mathrm{SEE}$ & 1.1818 & 0.8594 & 0.6563 & 0.1198 & 0.0488 & 0.0209 \\
Intra-particle diffusion & & & & & -0.16 \\
$\mathrm{c}$ & -1.05 & -0.70 & -0.29 & -0.49 & -0.49 & -0.16 \\
$\mathrm{k}_{\mathrm{p}}$ & 2.3371 & 2.1586 & 1.0365 & 0.4275 & 0.3647 & 0.1706 \\
SEE & 0.9196 & 0.6165 & 0.5137 & 0.1945 & 0.1613 & 0.0535 \\
\hline
\end{tabular}




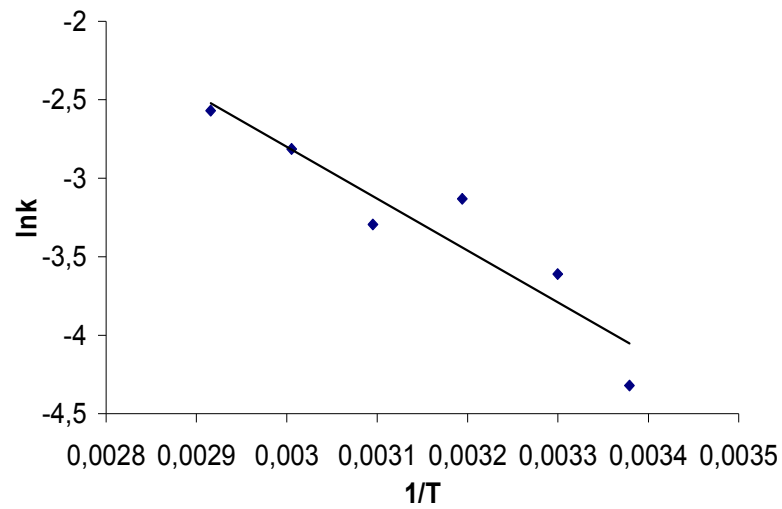

Fig. 6 Effect of temperature.

Table 3 Column models parameters of Methylene Blue adsorption on coffee residues.

\begin{tabular}{|c|c|c|c|c|c|c|c|}
\hline & $C_{\mathrm{i}}(\mathrm{mg} / \mathrm{L})$ & $\mathrm{Q}(\mathrm{mL} / \mathrm{min})$ & $n$ & $\mathrm{~N}(\mathrm{mg} / \mathrm{L})$ & $\mathrm{K}$ & $\mathrm{Q}_{0}(\mathrm{mg} / \mathrm{g})$ & SEE \\
\hline \multicolumn{8}{|l|}{$x=15 \mathrm{~cm}$} \\
\hline Bohart-Adams & 165 & 20 & 2.000 & 42,798 & 0.000080 & 96.90 & 2.3110 \\
\hline Clark & 165 & 20 & 1.612 & 40,522 & 0.000060 & 91.76 & 2.3053 \\
\hline Bohart-Adams & 130 & 40 & 2.000 & 29,317 & 0.001400 & 66.39 & 0.4876 \\
\hline Clark & 130 & 40 & 1.612 & 26,317 & 0.000100 & 59059 & 0.6402 \\
\hline Bohart-Adams & 150 & 70 & 2.000 & 31,482 & 0.000250 & 71.29 & 5.8235 \\
\hline Clark & 150 & 70 & 1.612 & 28,382 & 0.000220 & 64.27 & 5.1515 \\
\hline Bohart-Adams & 145 & 80 & 2.000 & 24,745 & 0.000210 & 56.03 & 7.5229 \\
\hline Clark & 145 & 80 & 1.612 & 20,673 & 0.000180 & 46.80 & 6.3513 \\
\hline Bohart-Adams & 800 & 20 & 2.000 & 46,166 & 0.000020 & 104.54 & 38.2861 \\
\hline Clark & 800 & 20 & 1.612 & 33,869 & 0.000010 & 76.69 & 32.5900 \\
\hline Bohart-Adams & 1,600 & 10 & 2.000 & 30,224 & 0.000010 & 68.44 & 102.8607 \\
\hline Clark & 1,600 & 10 & 1.612 & 22,024 & 0.000010 & 49.87 & 93.8242 \\
\hline Bohart-Adams & 1,600 & 20 & 2.000 & 36,641 & 0.000020 & 82.97 & 103.0998 \\
\hline Clark & 1,600 & 20 & 1.612 & 25,017 & 0.000020 & 56.64 & 903.4492 \\
\hline \multicolumn{8}{|l|}{$x=25 \mathrm{~cm}$} \\
\hline Bohart-Adams & 150 & 70 & 2.000 & 38,290 & 0.000160 & 86.65 & 4.0545 \\
\hline Clark & 150 & 70 & 1.612 & 35,501 & 0.000130 & 80.34 & 3.7795 \\
\hline Bohart-Adams & 800 & 20 & 2.000 & 21,788 & $2.25 \mathrm{E}-05$ & 49.30 & 62.5900 \\
\hline Clark & 800 & 20 & 1.612 & 16,007 & $1.98 \mathrm{E}-05$ & 36.20 & 56.0000 \\
\hline Bohart-Adams & 550 & 40 & 2.000 & 32,847 & $8.61 \mathrm{E}-05$ & 74.30 & 17.6150 \\
\hline Clark & 550 & 40 & 1.612 & 30,028 & $7.51 \mathrm{E}-05$ & 68.00 & 14.6410 \\
\hline
\end{tabular}

Table 4 Methylene Blue adsorption capacity for various lignocellulosic materials.

\begin{tabular}{|c|c|c|c|c|c|}
\hline Adsorbents & Pretreatment & $K_{F}\left[\left(\mathrm{mg} \cdot \mathrm{g}^{-1}\right)\left(\mathrm{L} \cdot \mathrm{mg}^{-1}\right)^{1 / \mathrm{n}}\right.$ & $n$ & $q_{\mathrm{m}}\left(\mathrm{mg} \cdot \mathrm{g}^{-1}\right)$ & $K_{\mathrm{L}}\left(\mathrm{L} \cdot \mathrm{mg}^{-1}\right)$ \\
\hline $\begin{array}{l}\text { Activated carbon } \\
\text { fibers }\end{array}$ & $\begin{array}{l}\text { Chenmical vapor } \\
\text { deposition modified }\end{array}$ & 120.000 & 1.460 & 478.00 & 0.3750 \\
\hline Cocoa & carbonized, burn & 40.850 & 8.090 & 212.77 & 0.2690 \\
\hline $\begin{array}{l}\text { (The obroma cacoa) } \\
\text { shell }\end{array}$ & activated & & & & \\
\hline Coffee residues & - & 3.555 & 1.612 & 78.90 & 0.0230 \\
\hline $\begin{array}{l}\text { Commercial } \\
\text { activated carbon }\end{array}$ & & - & - & 370.40 & 1.0500 \\
\hline Cotton stalk & - & 50.440 & 6.150 & 147.06 & 0.0249 \\
\hline Cotton stalk & sulfuric acid treated & 202.210 & 1.810 & 555.56 & 0.6207 \\
\hline
\end{tabular}


Table 4 continued

\begin{tabular}{|c|c|c|c|c|c|}
\hline Adsorbents & Pretreatment & $K_{F}\left[\left(\mathrm{mg} \cdot \mathrm{g}^{-1}\right)\left(\mathrm{L} \cdot \mathrm{mg}^{-1}\right)^{1 / \mathrm{n}}\right.$ & $n$ & $q_{\mathrm{m}}\left(\mathrm{mg} \cdot \mathrm{g}^{-1}\right)$ & $K_{\mathrm{L}}\left(\mathrm{L} \cdot \mathrm{mg}^{-1}\right)$ \\
\hline Cotton stalk & $\begin{array}{l}\text { phosphoric acid } \\
\text { treated }\end{array}$ & 157.910 & 16.150 & 222.22 & 14.516 \\
\hline $\begin{array}{l}\text { Date pits activated } \\
\text { carbon }\end{array}$ & $\begin{array}{l}\text { Pyrolyzed, } \mathrm{FeCl}_{3} \\
\text { activated }\end{array}$ & 74.871 & 4.670 & 249.46 & 0.0830 \\
\hline $\begin{array}{l}\text { Date stones activated } \\
\text { carbon }\end{array}$ & $\begin{array}{l}\text { Pyrolyzed, } \mathrm{ZnCl}_{2} \\
\text { activated }\end{array}$ & 71.190 & 3.440 & 369.38 & 0.0429 \\
\hline $\begin{array}{l}\text { Enteromorph a } \\
\text { prolifera activated } \\
\text { carbon }\end{array}$ & $\mathrm{ZnCl}_{2}$ activated & 236.230 & 3.720 & 270.27 & 1.2300 \\
\hline Graphene & - & 90.920 & 5.710 & 153.85 & 1.4400 \\
\hline Jojoba (defatted) & - & 1.132 & 1.054 & 167.00 & 0.0009 \\
\hline Palm kernel fiber & - & 8.670 & 1.770 & 95.40 & 0.0317 \\
\hline Peanut husk & - & 16.650 & 3.270 & 72.13 & 0.0850 \\
\hline Pine sawdust & Autohydrolyzed & 15.680 & 2.582 & 88.02 & 0.1072 \\
\hline Pistachio hull & - & 112.300 & 4.200 & 389.00 & 0.0960 \\
\hline $\begin{array}{l}\text { Posidonia oceanic } \\
\text { (L.) dead leaves } \\
\text { activated carbon }\end{array}$ & $\begin{array}{l}\text { Carbonized, } \mathrm{ZnCl}_{2} \\
\text { activated }\end{array}$ & 112.120 & 2.740 & 217.390 & 1.7000 \\
\hline Sugar beet pulp & - & 12.520 & 1.990 & 244.600 & 0.0149 \\
\hline Sugar beet pulp & - & 2.777 & 10.128 & 714.290 & 0.0039 \\
\hline Tea (rejected) & $\mathrm{NaOH}$ modified & 40.870 & 2.110 & 242.110 & 0.1300 \\
\hline $\begin{array}{l}\text { Turbinaria } \\
\text { turbinaria } \text { alga }\end{array}$ & - & 14.000 & 2.310 & 63.000 & 0.1830 \\
\hline $\begin{array}{l}\text { Turbinaria } \\
\text { turbinaria alga }\end{array}$ & pyrolyzed & 40.000 & 3.030 & 163.000 & 0.1040 \\
\hline $\begin{array}{l}\text { Turbinaria } \\
\text { turbinaria alga }\end{array}$ & $\begin{array}{l}\text { pyrolyzed, physically } \\
\text { activated }\end{array}$ & 105.000 & 3.630 & 411.000 & 0.0830 \\
\hline $\begin{array}{l}\text { Turbinaria } \\
\text { turbinaria alga }\end{array}$ & $\begin{array}{l}\text { pyrolyzed, } \\
\text { chemically activated }\end{array}$ & 137.000 & 5.670 & 345.000 & 0.136 \\
\hline Wheat straw & Acid hydrolyzed & 10.950 & 1.010 & 20.410 & 0.663 \\
\hline
\end{tabular}

Table 5 Adsorption capacity of various coffee residues/byproducts.

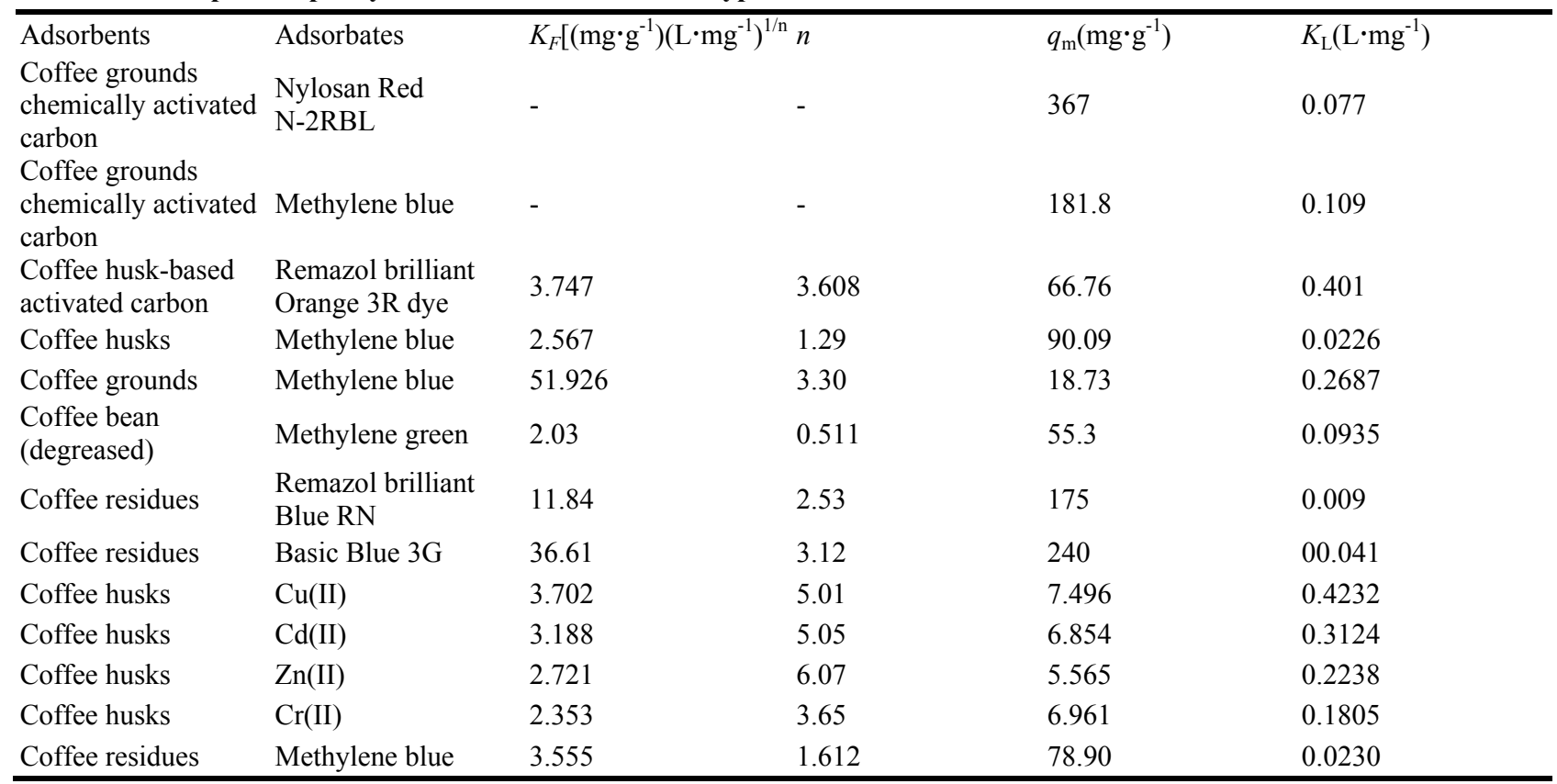




\section{Conclusions}

The use of coffee residues is an innovative technique using waste biomass from urban and rural areas in and Industrial Ecology framework. Also, that is an index of the sensitivity of citizens for the rational management of waste and their contribution to sustainable development. The present work proves the viability of using coffee residues to remove basic dyes like MB from wastewaters. The effect of different system parameters on (a) batch and (b) continuous fixed-bed column systems were studied. The experimental systems data were simulated using the most commonly used isotherm and kinetic models. The continuous fixed-bed column results proved that the $\mathrm{MB}$ is practically adsorbed on coffee residues giving maximum Bohart and Adams capacity $N=46,166$ $\mathrm{mg} \cdot \mathrm{L}^{-1}$ or $q_{0}=104.5 \mathrm{mg} \cdot \mathrm{g}^{-1}$ for bed-depth $15 \mathrm{~cm}$, initial dye concentration $800 \mathrm{mg} \cdot \mathrm{L}^{-1}$ and flow rate 20 $\mathrm{mL} \cdot \mathrm{min}^{-1}$. These results provide evidence for suggesting this low cost residue for the removal of basic dyes in industrial scale applications.

\section{References}

[1] Radoykova, T., Dimitrova, S. V., Aleksieva, K. I., Nenkova, S. K., Valchev, I. V., and Mehandjiev, D. R. 2015. "Comparative $\mathrm{Mn}^{2+}$ Adsorption on Waste Lignocellulosic Materials.” Journal of Environmental Protection and Ecology 16 (1): 23-32.

[2] Bungau, S., Bungau, C., and Tit, D. M. 2015. "Studies on the Last Stage of Product Lifecycle Management for a Pharmaceutical Product." Journal of Environmental Protection and Ecology 16 (1): 56-62.

[3] Turkmenler, H., and Aslan, M. 2015. "Management of Waste Sludge in Pasakoy Advanced Biological Wastewater Treatment Plant." Journal of Environmental
Protection and Ecology 16 (1): 214.

[4] Robinson, T., Mcmullan, G., Marchant, R., and Nigam, P. 2001. "Remediation of Dyes in Textile Effluent: A Critical Review on Current Treatment Technologies with a Proposed Alternative." Bioresour. Technol. 77 (3): 247-55.

[5] Sparado, J. T., Gold, M. H., and Renganathan, V. 1992. "Degradation of Azo Dyes by Lignin Degrading Fungus Penicillium chrysosporium." Appl. Environ. Microbiol. 58 (8): 2397-401.

[6] Mastrangelo, G., Fedeli, U., Fadda, E., Mila, G., and Lange, J. 2002. "Epidermiologic Evidences of Cancer Risk in Textile Industry Workers:A Review and Update." Toxicol. Industr. Health 18 (4): 171-81.

[7] Song, J., Zou, W., Bian, Y., Su, F., and Han, R. 2011. "Adsorption Characteristics of Methylene Blue by Peanut Husk in Batch and Column Modes.” Desalination 265 (1): 119-25.

[8] Deng, H., Lu, J., Li, G., Zhang, G., and Wang, X. 2011. "Adsorption of Methylene Blue on Adsorbent Materials Produced from Cotton Stalk." Chem. Eng. J. 172 (1): 326-34.

[9] Sohrabi, M. R. and Ghavami, M. 2008 "Photocatalytic Degradation of Direct Red 23 Dye Using $\mathrm{UV} / \mathrm{TiO}_{2}$ : Effect of Operational Parameters." J. Hazard. Mater. 153 (3): 1235-9.

[10] Ciardelli, G., Corsi, L., and Marcucci, M. 2001. "Membrane Seperation for Watewater Reuse in the Textile Industry." Resour. Conserv. Recycl. 31 (22): 189-97.

[11] Tang, H., Yin, L., and Lu, H. 2012. "Synthesis, Conformations and Cell-Penetrating Properties." Biomacromolecules 13: 2609.

[12] Rafatullah, M., Sulaiman, O., Hashim, R., and Ahmad, A. 2010. "Adsorption of Methylene Blue on Low-Cost Adsorbents: A review.” J. Hazard. Mater. 177 (1): 70-80.

[13] El-Sayed, A. M., Mitchell, V., Manning, L. A., Cole, L., and Suckling, D. M. 2011. "New Sex Pheromone Blend for the Lightbrown Apple Moth, Epiphyas Postvittana." $J$. Chem. Ecol. 37 (6): 640. 